\title{
HUBUNGAN KINERJA OTAK DAN SPIRITUALITAS MANUSIA DIUKUR DENGAN MENGGUNAKAN INDONESIA SPIRITUAL HEALTH ASSESSMENT PADA PEMUKA AGAMA DI KABUPATEN HALMAHERA TENGAH
}

\author{
${ }^{1}$ Rezky A. Yastab \\ ${ }^{2}$ Taufiq Pasiak \\ ${ }^{2}$ Sunny Wangko
}

\author{
${ }^{1}$ Kandidat Skripsi Fakultas Kedokteran Universitas Sam Ratulangi Manado \\ ${ }^{2}$ Bagian Anatomi-Histologi Fakultas Kedokteran Universitas Sam Ratulangi Manado \\ Email: ryastab@yahoo.com
}

\begin{abstract}
Human brain contains 100 billions of nerve cells which have a complex function as the control center of all human activities. Related to the brain function, neuroscience emerges, focusing on the nervous system especially the neuron cells. The neuroscience has also significant interest in the relation of human to God. Spirituality refers to things that deal with the spirit or soul, and not attributable to physical nature. Its material consists of two variables: spirituality and domination of the brain. Indonesia Spiritual Health Assessment (ISHA) is an assessment based on the concept of theoretical spirituality. ISHA has three components, namely spiritual health item, examination the brain system assessment, and neurofeedback. This study aimed to obtain the relation of brain with human spirituality in the performance of religion leaders in middle Halmahera. This was a descriptive study with a cross sectional design. Samples were 55 religion leaders. The Spearman correlation test showed a value of sig $>\alpha$ with a significance of 0,05 . The analytical results showed that the correlation between the limbic system and ritual 0.806; between the prefrontal cortex and the meaning of life 0.833; and between the prefrontal cortex and spiritual experience 0.091. Conclusion: There was no correlation between brain performance and spirituality of the religion leaders in middle Halmahera.

Keywords: brain, neuroscience, spirituality, ISHA
\end{abstract}

\begin{abstract}
Abstrak: Otak manusia tersusun oleh sekitar 100 miliar sel neuron dengan fungsi kompleks sebagai pusat pengendali seluruh aktivitas manusia. Terkait dengan keberadaan otak, berkembang disiplin ilmu neurosains yang khusus mempelajari sistem saraf, terutama neuron, serta hubungan manusia dan Tuhan. Spiritualitas yaitu segala sesuatu yang berhubungan dengan roh atau jiwa, dan tidak berkaitan dengan alam fisik/jasmaniah. Materi spiritualitas terdiri dari 2 variabel yaitu spiritualitas dan dominasi otak. Indonesia Spiritual Health Assessment (ISHA) adalah asesmen yang dibuat berdasarkan konsep teoritis spiritualitas, yang terdiri dari tiga komponen pemeriksaan yaitu Spiritual Health Item, Brain System Assessment, dan neurofeedback. Penelitian ini bertujuan untuk mengetahui hubungan kinerja otak dan spiritualitas manusia pada pemuka agama di Kabupaten Halteng. Penelitian ini bersifat deskriptif dengan pendekatan cross sectional. Sampel penelitian ialah 55 pemuka agama. Uji korelasi Spearman menunjukkan koefesien nilai sig $>\alpha$ dan taraf kemaknaan 0,05. Hasil analisis memperlihatkan korelasi antara sistem limbik dan ritual 0,806, antara korteks prefrontal dan makna hidup 0,833, serta antara korteks prefrontal dan pengalaman spiritual 0,091. Simpulan: Tidak terdapat hubungan antara kinerja otak dan spiritualitas pada pemuka agama di Kabupaten Halteng diukur dengan ISHA.
\end{abstract}

Kata kunci: otak, neurosains, spiritualitas, ISHA 
Otak manusia terususn oleh sekitar 100 miliar sel saraf dengan fungsi yang kompleks sebagai pusat pengendali seluruh aktivitas manusia. ${ }^{1}$ Terkait dengan keberadaan otak, berkembang disiplin ilmu neurosains yang khusus membahas masalah otak dan sistem saraf terutama sel-sel neuron. ${ }^{2}$

Kesehatan adalah keadaan sehat, baik secara fisik, mental, spritual maupun sosial yang memungkinkan setiap orang untuk hidup produktif secara sosial dan ekonomis. ${ }^{3}$ Spiritual merupakan esensi dari kesehatan dan kesejahteraan manusia.

Spiritual dibedakan dengan agama, dimana agama berarti menganut satu agama dan juga berarti kita masuk dalam suatu komunitas. Oleh sebab itu, agama atau beragama membuat manusia itu berbeda dengan manusia lainnya dalam hal status, sedangkan spiritual lebih bersifat individualistik, yang terfokus pada bagaimana seseorang melaksanakan halhal yang dianggapnya benar dan yang dipercayai. ${ }^{4}$

Indonesia menggunakan alat ukur yang disebut Indonesia Spiritual Health Assessment (ISHA) yang merupakan uji yang dibuat oleh tim Centre for Neuroscience, Health and Spirituality (CNET). Uji ini berbasis neurosains, dan juga memuat tentang profil spiritual manusia sehingga kita dapat mengetahui kecenderungan manusia berlaku sesuai dengan nilai-nilai agama. ${ }^{5}$

\section{METODE PENELITIAN}

Penelitian ini dilakukan di Kabupaten Halmahera Tengah. Penelitian ini bersifat deskriptif dengan pendekatan cross sectional. Populasi penelitian ialah semua pemuka agama di Kabupaten Halmahera Tengah selama bulan NovemberDesember 2013. Sampel penelitian ialah semua pemuka agama Islam dan Kristen (Katolik dan Protestan). Data diambil dengan cara membagikan kuesioner berupa Indonesia Spiritual Health Assessment (ISHA) kepada sebanyak 55 responden.
Data dianalisis menggunakan korelasi Spearman.

\section{HASIL PENELITIAN}

\section{Karakteristik reponden}

Responden yang ikut dalam penelitian ini ialah pemuka agama di Kabupaten Halmahera Tengah. Karakteristik responden dapat dilihat pada Tabel 1.

Tabel 1. Distribusi frekuensi usia dan jenis kelamin responden

\begin{tabular}{lccc}
\hline $\begin{array}{l}\text { Kelompok } \\
\text { Usia } \\
\text { (tahun) }\end{array}$ & $\begin{array}{c}\text { Jenis Kelamin } \\
\text { Laki-laki } \\
(\mathbf{\%})\end{array}$ & $\begin{array}{c}\text { Perempuan } \\
(\mathbf{\%})\end{array}$ & $\begin{array}{c}\text { Jumlah } \\
\mathbf{n} \\
\mathbf{( \% )}\end{array}$ \\
\hline$\geq 40$ & 16 & 7 & 23 \\
& $(69,6)$ & $(30,4)$ & $(100)$ \\
$<40$ & 20 & 12 & 32 \\
& $(62,5)$ & $(37,5)$ & $(100)$ \\
\multirow{4}{*}{ total } & 36 & 19 & 55 \\
& $(65,5)$ & $(34,5)$ & $(100)$ \\
\hline
\end{tabular}

Sampel yang digunakan berjumlah 55 orang. Presentase responden yang berjenis kelamin laki-laki 65,5 \% sedangkan yang berjenis kelamin perempuan 34,5 \%.

Berdasarkan kelompok usia, yang berusia $\geq 40$ tahun laki-laki berjumlah 16 orang (69,6\%), sedangkan perempuan berjumlah 7 orang $(30,4 \%)$. Responden laki-laki yang berusia $<40$ tahun berjumlah 20 orang $(62,5 \%)$, sedangkan responden perempuan yang berusia $<40$ tahun berjumlah 12 orang (37,5\%).

\section{Hasil interpretasi ISHA}

Indonesia Spiritual Health Assessment yang dibagikan kepada responden terbagi atas 2 komponen yaitu spiritualitas dan dominasi otak. Hasil ini juga dikategorikan menjadi 3 yaitu excellent (sangat baik), moderate (baik), dan improved (cukup baik).

Hasil pengolahan data dari kuesioner yang diberikan kepada responden untuk 
komponen spiritualitas dapat dilihat di Tabel 2.

Tabel 2. Hasil ISHA spiritualitas

\begin{tabular}{lcllll}
\hline JK & Interpretasi & PS & EP & MH & R \\
\hline L & E & 9 & 17 & 27 & 26 \\
& M & 25 & 19 & 8 & 10 \\
& I & 2 & 0 & 1 & 0 \\
\hline P & E & 5 & 12 & 12 & 13 \\
& M & 13 & 7 & 7 & 6 \\
& I & 1 & 0 & 0 & 0 \\
\hline
\end{tabular}

Berdasarkan Tabel 2, pengalaman spiritual pada responden laki-laki yang excellent berjumlah 9 orang, moderate 25 orang, dan improved 2 orang, sedangkan untuk pengalaman spiritual pada responden perempuan yaitu excellent 5 orang, moderate 13 orang, dan improved 1 orang.

Emosi positif pada responden laki-laki yang excellent berjumlah 17 orang dan moderate 19 orang, sedangkan pada responden perempuan excellent 12 orang dan moderate 7 orang.

Makna hidup pada responden laki-laki yang excellent berjumlah 27 orang, 8 orang moderate, dan improved 1 orang, sedangkan pada responden perempuan didapatkan hasil 12 orang excellent dan 7 orang moderate.

Ritual pada responden laki-laki yang excellent 26 orang dan moderate 10 orang, sedangkan pada responden perempuan excellent 13 orang dan moderate 6 orang.

Hasil pengolahan data dari kuesioner untuk komponen dominasi otak dapat dilihat di Tabel 3.

Tabel 3. Hasil ISHA Dominasi Otak

\begin{tabular}{lllllll}
\hline JK & Interpretasi & KP & SL & GB & GS & LT \\
\hline L & E & 22 & 4 & 19 & 18 & 22 \\
& M & 14 & 31 & 17 & 17 & 13 \\
& I & 0 & 1 & 0 & 1 & 1 \\
\hline P & E & 11 & 2 & 10 & 3 & 12 \\
& M & 8 & 16 & 9 & 15 & 7 \\
& I & 0 & 1 & 0 & 1 & 0 \\
\hline
\end{tabular}

Tabel 3 menunjukkan bahwa korteks prefontalis pada responden laki-laki yang excellent 22 orang dan moderate 14 orang, sedangkan pada responden perempuan didapatkan excellent 11 orang dan moderate 8 orang.

Sistem limbik pada responden laki-laki terdapat 4 orang excellent, 31 orang moderate dan 1 orang improved, sedangkan untuk sistem limbik pada responden perempuan 2 orang excellent, 16 orang moderate dan 1 orang improved.

Ganglia basalis pada responden lakilaki yang excellent 19 orang dan moderate 9 orang, sedangkan pada responden perempuan didapatkan excellent 10 orang dan 9 orang moderate.

Girus singulat pada responden laki-laki yang excellent 18 orang, moderate 17 orang, dan improved 1 orang, sedangkan untuk responden perempuan 3 orang untuk excellent, 15 orang moderate, dan 1 orang improved.

Juga didapatkan bahwa lobus temporalis pada responden laki-laki yang excellent 22 orang, moderate 13 orang dan improved 1 orang, sedangkan pada responden perempuan dengan hasil excellent 12 orang dan moderate 7 orang.

\section{Hasil analisis data}

Untuk menilai kemaknaan hubungan antara dua variabel dapat dilihat pada tarak kemaknaan yang ditentukan dengan nilai sig $<\alpha$. Taraf kemaknaan yang ditentukan disini ialah 0,05. Untuk mengetahui kuat lemahnya hubungan yang ada dilihat dari nilai yang ada pada tabel antara -1 dan +1 , yang artinya jika nilai $r$ semakin mendekati +1 berarti menunjukkan hubungan positif yang kuat sedangkan jika nilai $r$ semakin mendekati -1 mengindikasikan hubungan negatif yang kuat.. ${ }^{6}$

Untuk menilai hasil uji korelasi antara kinerja otak dan spiritualitas, pada penelitian ini akan dibahas beberapa hubungan antar komponen dari ISHA, antara lain:

a. Hubungan sistem limbik dan ritual. Pada penelitian yang dilakukan oleh Jendy (2012-2013) didapatkan 
hubungan antara sistem limbik dengan ritual walaupun hubungan antara kedua variabel lemah. ${ }^{7}$ Pada perhitungan korelasi yang dilakukan penulis mendapatkan hasil nilai sig $0,806>\alpha$ dengan nilai koefesien 0,034 artinya tidak ada hubungan antara kedua variable (Tabel 4)

Tabel 4. Output Korelasi Hubungan Sistem Limbik dengan Ritual

\section{Correlations}

\begin{tabular}{llll}
\hline \multicolumn{2}{l}{ Spearman's rho } & \multicolumn{1}{c}{$\mathbf{R}$} & \multicolumn{1}{c}{ SL } \\
\hline Ritual & Correlation & 1.000 & .034 \\
& Coefficient & & \\
& Sig.(2-tailed) &. & .806 \\
& $\mathrm{~N}$ & 55 & 55 \\
\hline Sistem & Correlation & .034 & 1.000 \\
limbik & Coefficient & .034 & \\
& Sig.(2-tailed) & .806 &. \\
& $\mathrm{~N}$ & 55 & 55 \\
\hline
\end{tabular}

b. Hubungan korteks prefrontal dan makna hidup. Pada penelitian yang dilakukan oleh Fitria (2012-2013) didapatkan hubungan antara korteks prefrontal dengan makna hidup walaupun hubungan antara kedua variabel lemah. ${ }^{8}$ Hasil analisis yang didapatkan penulis nilai sig $0,833>\alpha$ dengan nilai koefesien 0,029 artinya tidak ada hubungan antara kedua variable (Tabel 5).

Tabel 5. Output Korelasi Hubungan Korteks Prefrontal dengan Makna Hidup

Correlations

\begin{tabular}{|c|c|c|c|}
\hline \multicolumn{2}{|c|}{ Spearman's rho } & \multirow{2}{*}{$\frac{\mathrm{MH}}{1.000}$} & \multirow{2}{*}{$\frac{\mathrm{CP}}{.029}$} \\
\hline $\mathrm{MH}$ & $\begin{array}{l}\text { Correlation } \\
\text { Coefficient }\end{array}$ & & \\
\hline \multirow{4}{*}{ CP } & $\begin{array}{l}\text { Sig.(2-tailed) } \\
\mathrm{N}\end{array}$ & 55 & $\begin{array}{l}.833 \\
55 \\
\end{array}$ \\
\hline & $\begin{array}{l}\text { Correlation } \\
\text { Coefficient }\end{array}$ & .029 & 1.000 \\
\hline & Sig. (2-tailed) & 833 & \\
\hline & $\mathrm{N}$ & 55 & 55 \\
\hline
\end{tabular}

c. Hubungan korteks prefrontal dengan pengalaman spiritual. Hasil analisis yang didapatkan menunjukkan nilai sig 0,091> $\alpha$ dengan nilai koefesien 0,230 artinya tidak ada hubungan antara kedua variabel tersebut yang di ukur dengan menggunakan Indonesia Spiritual Health Assessment (ISHA) (Tabel 6).

Tabel 6. Output Korelasi Korteks Prefrontal dengan Pengalaman Spiritual

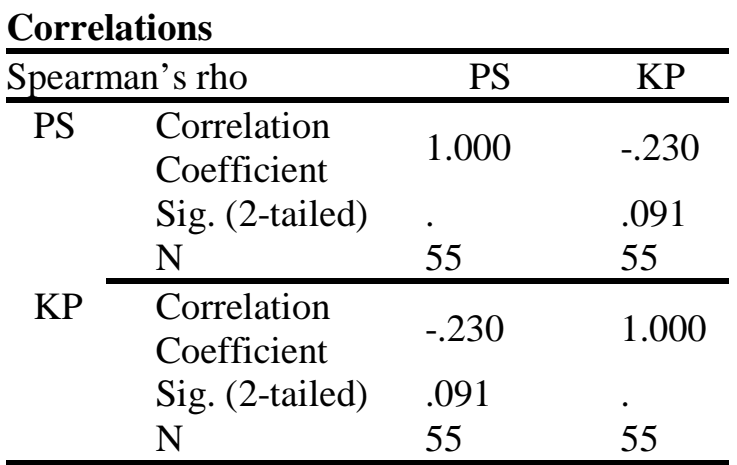

\section{BAHASAN}

\section{Hubungan sistem limbik dan ritual.}

Sistem limbik merupakan sistem yang terdiri dari subsistem yang berfungsi untuk mem-back up emosi manusia. ${ }^{2}$ Sistem limbik dibangun oleh sejumlah struktur, yaitu hipotalamus, amigdala, dan hipokampus. Hipotalamus merupakan sistem utama pengatur hormon-hormon tubuh. ${ }^{2}$ Sistem limbik berfungsi menghasilkan perasaan, mengatur produksi hormon, memelihara homeostasis, rasa haus, rasa lapar, dorongan seks, pusat rasa senang, dan juga memori jangka panjang manusia. ${ }^{3}$

Ritual merupakan manifestasi spiritualitas berupa tindakan terstruktur, sistematis, berulang, melibatkan aspek motorik, kognisi, afektif, yang dilakukan menurut suatu tata cara tertentu baik individual maupun komunal. ${ }^{2}$ Bentukbentuk ritual dapat berupa sembahyang, berdoa, mengunjungi tempat ibadah, dan memberi sedekah. ${ }^{4}$ 
Secara neurobiologis, kegiatan ritual merupakan perilaku yang: ${ }^{4}$

a. Terstruktur atau terpola, seperti shalat dalam Islam, berdoa dalam berbagai agama, dan menari dalam tarian suci.

b. Berirama dan berulang, pada saat shalat atau liturgi tertentu dalam tradisi Kristiani, diwajibkan gerakan yang dilakukan berulang-ulang dan berirama

c. Integrasi emosi, rasio, dan aksi. Kegiatan ritual mewajibkan pelakunya untuk sadar dan aware. Pengetahuan tentang ritual merupakan syarat penting berlangsungnya sebuah ritual dengan baik dan sesuai sasaran.

d. Dilakukan oleh banyak orang dan mempunyai sinkronisasi, seperti doa massal, meditasi massal, dan zikir akbar.

Dari bahasan di atas diketahui bahwa terdapat hubungan antara sistem limbik dan ritual, walaupun hasil analisis SPSS menyatakan kedua hal ini tidak berhubungan. Sistem limbik ialah sistem yang mengatur emosi manusia, dan kegiatan ritual itu melahirkan kondisi emosi manusia terhadap Tuhan. Mereka yang melakukan kegiatan ritual dengan baik seperti berdoa dan sholat memiliki fungsi fisiologik tubuh yang baik; juga hal ini dikarenakan kegiatan ritual ini memberikan pengaruh signifikan terhadap sistem limbik dan fungsi-fungsi ini diatur oleh hipotalamus yang juga bagian dari sistem limbik. $^{4}$

\section{Hubungan korteks prefrontal dan makna hidup}

Korteks prefrontalis, yang terletak di bagian atas depan berperan penting dalam fungsi kognitif dan fungsi eksekutif seperti memusatkan perhatian, membuat rencana, mengendalikan dorongan hati, dan membuat keputusan (baik atau buruk). Pada wilayah ini juga berfungsi sebagai ekspresi kepribadian, pengambilan keputusan dan perilaku sosial yang benar. ${ }^{9}$
Makna hidup merupakan manifestasi dari spiritualitas berupa penghayatan intrapersonal yang bersifat unik, ditunjukkan dalam hubungan sosial (interpersonal) yang bermanfaat, menginspirasi, dan mewariskan sesuatu yang bernilai bagi kehidupan manusia. ${ }^{4}$ Makna hidup membuat seseorang memiliki nilai dalam hidupnya. Makna hidup memiliki kaitan langsung dengan kesehatan manusia tidak hanya kesehatan fisilk, tetapi

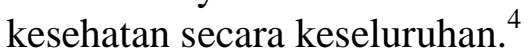

Kehilangan makna hidup dapat berarti munculnya penyakit. Keberadaan makna hidup merupakan sumber bagi kesehatan, baik kuratif, promotif, maupun rehabilitatif. ${ }^{4}$ Kerusakan pada korteks prefrontal akan membuat seseorang kehilangan fungsi-fungsi kortes prefrontal yang berakhir pada kehilangan makna hidup. Kasus-kasus yang dilaporkan dalam ilmu kedokteran menunjukkan bahwa kerusakan pada lobus frontal terutama korteks prefrontal akan membuat seseorang berubah kepribadiannya. ${ }^{4}$

Makna hidup ini dapat terjadi karena adanya fungsi otak dalam hal ini tiga fungsi yang dilakukan oleh korteks prefrontalis, yaitu: $^{4}$

a. Merencanakan masa depan.

Manusia mengerjakan banyak sekali kegiatan yang akan menopang masa depannya disebabkan manusia menginginkan masa depannya lebih baik dari hari ini. Hal ini diatur oleh korteks prefrontalis yang jika rusak maka manusia akan kehilangan kemampuannya untuk merencanakan masa depan seperti janji untuk bertemu di kemudian hari.

b. Membuat keputusan.

Ketrampilan membuat keputusan menandai ketrampilan berpikir. Nalar, analisis, observasi, dan asosiasi ialah sedikit ketrampilan yang harus dimiliki untuk membuat keputusan secara baik dan tepat. Keputusan ini menjadi penting karena kehidupan yang diarahkan oleh cara berpikir 
yang tepat akan menghasilkan tindakan yang baik juga sehat.

c. Membuat nilai-nilai dan penilaian. Korteks prefrontal berhubungan dengan kehidupan sosial seseorang. Harlow, seorang dokter yang menangani kasus Phineas Gage mengatakan bahwa potongan besi yang menembus otak bagian depan melalui tulang pipinya ini sekaligus merusak korteks prefrontalis Gage mengalami kerusakan kecakapan sosialnya, sehingga ia tidak memiliki kemampua untuk mengendalikan perilaku sosialnya.

Dari bahasan di atas dapat dilihat adanya hubungan antara korteks prefrontalis dengan makna hidup seseorang. Jika korteks prefrontalis ini baik maka ia akan mampu melakukan halhal yang bermanfaat bagi hidupnya juga dapat merencanakan hidupnya dengan lebih baik. Walaupun hal ini tidak sesuai dengan hasil analisis SPSS yang ditemukan yaitu tidak ada hubungan antara korteks prefrontal dengan makna hidup.

\section{Hubungan korteks prefrontal dan pengalaman spiritual}

Area prefrontal merupakan bagian terdepan dari lobus frontal dan lobus korteks terbesar yang berisi lima bidang utama untuk fungsi neuropsikiatri (planning, organizing, problem solving, selective attention, personallity) dan fungsi motorik serta memediasi fungsi intelektual yang tinggi. ${ }^{9}$

Area ini juga berfungsi sebagai ekspresi kepribadian, pengambilan keputusan dan perilaku sosial yang benar. Korteks prefrontal berperan penting untuk fungsi kognitif dan fungsi eksekutif seperti pembentukan niat dan pengendalian perhatian selain itu berperan untuk pengendalian diri, pengendalian terhadap perasaan negatif, dan dalam proses pengambilan keputusan. ${ }^{9}$

Pengalaman spiritual ialah aspek yang penting dalam pengukuran spiritualitas manusia. Pengalaman spiritual disini meliputi rasa kagum, rasa syukur, kasih sayang, dan keinginan untuk lebih dekat dengan Tuhan. Dengan mengeksplorasi pengalaman spiritual, individu lebih menyadari akan keterhubungan dengan Tuhan serta memiliki keyakinan bahwa pengampunan dan pertolongan dari Tuhan. ${ }^{10}$

Pengalaman spiritual banyak dihubungkan dengan hal-hal gaib. Sebenarnya pengalaman spiritual sendiri adalah pemaknaan dari sesuatu yang dialami. Seseorang bisa saja mengalami pengalaman yang biasa, contohnya dinasehati seorang pengemis, tapi orang tersebut memaknai kejadian tersebut sebagai hal yang luar biasa dan mengilhaminya untuk berpikir dan melakukan sesuatu yang lebih baik lagi. ${ }^{11}$

Pada penelitian sebelumnya oleh Liwarti (2013) didapatkan hubungan antara pengalaman spiritual dan psychological well-being (realisasi dan pencapaian penuh dari individu dapat menerima kekurangan dan kelebihan dirinya), spiritualitas juga energi yang menghubungkan manusia dan untuk mengenal dirinya lebih dalam dan merasa terhubung dengan Tuhan. Pada saat mengalami peristiwa yang menimbulkan perasaan sedih, ketakutan dan kehilangan kebanyakan orang akan kembali mengingat Tuhan dan menambah pengalaman-pengalaman spiritualitasnya. ${ }^{10}$

Pada bahasan diatas dapat diketahui bahwa pengalaman spiritual berhubungan dengan korteks prefrontal individu. Jika korteks prefrontal individu baik maka individu tersebut akan memahami dirinya dan berperilaku sebagai makhluk spiritual, yang dimana spiritual merupakan pemberi arah dan arti bagi kehidupan manusia dan dasar bagi tumbuhnya harga diri, nilainilai, moral, dan rasa memiliki bagi setiap individu, meskipun hal ini bertolak belakang dengan hasil analisis data sampel yang mengatakan bahwa tidak ada hubungan antara korteks prefrontal dengan pengalaman spiritual 


\section{SIMPULAN}

Dari hasil penelitian dapat disimpulkan bahwa tidak terdapat hubungan antara kinerja otak dengan spiritualitas manusia pada pemuka agama di Kabupaten Halmahera Tengah.

\section{SARAN}

Perlu penelitian lebih lanjut dengan waktu yang lebih lama dan jumlah responden yang lebih banyak, untuk mendapatkan hasil yang lebih baik dan akurat.

\section{UCAPAN TERIMA KASIH}

Ucapan terima kasih ditujukan kepada dr. Sonny J. R. Kalangi, MBiomed, PA(K) dan dr. George N. Tanudjaja, MS, PA(K) selaku penguji skripsi serta semua pihak yang telah menumbuhkan ide dan gagasan dalam penulisan ini.

\section{DAFTAR PUSTAKA}

1. Wulandari IP. Pembuatan alat ukur kecepatan respon manusia berbasis mikrokontroler. Jurnal Neutrino. 2009;1(2):208.

2. Hernanta I. Ilmu Kedokteran Lengkap tentang Neurosains. Yogyakarta: DMedika, 2013.

3. Undang-undang Republik Indonesia No.36 Tentang Kesehatan, Bab I Pasal 1 Tahun 2009.
4. Pasiak T. Tuhan dalam Otak Manusia. Bandung: Mizan, 2012.

5. Asesmen Spiritual untuk Periksa Integritas. 2013. [cited: 27/10/2013]. Available from: http://beritamanado. com/berita-utama/mou-kpk-dan-uinyogyakarta-asesmen-spiritual-untukperiksa-integrasi.

6. Sopiyudin MD. Statistik untuk Kedokteran dan Kesehatan. Jakarta: Penerbit Salemba Medika, 2008.

7. Jendy CD. Hubungan Kinerja Otak dengan Spiritualitas Manusia Diukur Menggunakan Indonesia Health Assessment pada Pemimpin Agama di Tomohon [Skripsi]. Manado: Fakultas Kedokteran Universitas Sam Ratulangi, 2012

8. Fitria AD. Hubungan Kinerja Otak dengan Spiritualitas Manusia Diukur Menggunakan Indonesia Health Assessment pada Dosen Sekolah Tinggi Agama Islam Negeri Manado [Skripsi]. Manado: Fakultas Kedokteran Universitas Sam Ratulangi, 2012

9. Hudori. Relasi kecerdasan spiritual dan pencarian jejak Tuhan. Jurnal Soul. 2008;1(2):48-50.

10. Liwarti. Hubungan pengalaman spiritual dengan Psychological Well-being pada penghuni Lembaga Pemasyarakatan. Jurnal Sains dan Praktik Psikologi. 2013;1(1):77-88.

11. Cahyono R. Dinamika emosi dan pengalaman spiritual beragama: Studi kualitatif pengalaman perubahan keyakinan beragama. Jurnal INSAN. 2013:1(13):34. 